\title{
Hypernatremia in a patient treated with sodium polystyrene sulfonate
}

\author{
This article was published in the following Dove Press journal: \\ International Journal of Nephrology and Renovascular Disease \\ 14 November 2010 \\ Number of times this article has been viewed
}

\author{
Manish Nepal \\ Ion Dan Bucaloiu \\ Evan R Norfolk \\ Geisinger Medical Center, \\ Department of Nephrology, \\ Danville, PA, USA
}

\begin{abstract}
Severe hyperkalemia requires urgent medical attention and correction in order to prevent arrhythmic complications. Sodium polystyrene sulfonate (SPS) is a cation exchange resin commonly used in the management of hyperkalemia. A recent review raised concerns regarding its effectiveness and potential adverse effects. Hypernatremia in adults in the setting of sodium polystyrene sulfonate therapy has not been described in the literature. We report the case of a woman who developed hypernatremia in the setting of excessive SPS administration and hope to increase awareness among clinicians regarding this potential side effect of SPS therapy.

Keywords: SPS, hyperkalemia

\section{Background}

Hyperkalemia is a medical emergency primarily due to its cardiotoxic effects. In addition to cardiac membrane stabilization with intravenous calcium and redistribution of cellular potassium with insulin, beta antagonists, or bicarbonate, therapy with a cation exchange resin is often used in order to promote net potassium loss in the intestinal tract. ${ }^{1,2}$ A recent review raised concerns regarding its effectiveness and potential adverse effects of this agent. ${ }^{3}$ Two cases of hypernatremia in the setting of sodium polystyrene sulfonate (SPS) treatment have been reported in neonates. ${ }^{4}$ We describe the case of an adult female patient who developed hypernatremia during treatment with SPS.
\end{abstract}

\section{Case report}

A 44-year-old female nursing home resident, with normal baseline renal function was admitted to the hospital for confusion and lethargy. She had poor oral intake for the week prior to admission and recently her narcotic medications have been increased for worsening back pain. Her outpatient medications included furosemide, spironolactone, and lisinopril. Her medical history was notable for cirrhosis due to hepatitis $\mathrm{C}$, hypothyroidism, hypertension, and chronic back pain. Initial evaluation revealed acute renal failure with creatinine of $5.1 \mathrm{mg} / \mathrm{dL}$ and hyperkalemia (7.1 mmol/L). Her initial serum sodium was normal $(140 \mathrm{mEq} / \mathrm{L})$; however, in the following hours she developed hyponatremia $(128 \mathrm{mEq} / \mathrm{L})$. On physical examination she appeared dehydrated and lethargic. Laboratory values on admission and subsequently on follow-up are presented in Table 1 . Her electrocardiogram revealed sinus tachycardia without T-wave changes.

She was treated with intravenous insulin and dextrose, intravenous saline infusion, and SPS (60 g every 6 hours). Her urine output improved, and the patient
Correspondence: Manish Nepal Nephrology, Geisinger Medical Center, Danville, PA I7822, USA

$\mathrm{Tel}+|57027| 6393$

$\mathrm{Fax}+\mathrm{I} 57027 \mid 5623$

Email mnepall @geisinger.edu 
Table I Results of laboratory tests ${ }^{a}$

\begin{tabular}{|c|c|c|c|c|c|c|c|c|}
\hline \multirow[t]{2}{*}{ Variables } & \multirow{2}{*}{$\begin{array}{l}\text { Normal } \\
\text { values }\end{array}$} & \multicolumn{4}{|c|}{ Day 0 (Hours after admission) } & \multirow[t]{2}{*}{ Day I } & \multirow[t]{2}{*}{ Day 2} & \multirow[t]{2}{*}{ Day 3} \\
\hline & & $\begin{array}{l}\text { I hour } \\
\text { (SPS given) }\end{array}$ & $\begin{array}{l}6 \text { hours } \\
\text { (SPS given) }\end{array}$ & $\begin{array}{l}\text { I } 2 \text { hours } \\
\text { (SPS given twice) }\end{array}$ & 16.5 hours & & & \\
\hline $\begin{array}{l}\text { Sodium } \\
\text { (mmol/L) }\end{array}$ & $135-145$ & 140 & 128 & $14 \mid$ & 149 & $15 \mid$ & 143 & 140 \\
\hline $\begin{array}{l}\text { Potassium } \\
(\mathrm{mmol} / \mathrm{L})\end{array}$ & $3.8-4.8$ & 7.1 & 7.5 & 8.7 & 6.1 & 5.2 & 4.2 & 3.7 \\
\hline $\begin{array}{l}\text { Chloride } \\
\text { (mmol/L) }\end{array}$ & $100-108$ & 95 & 98 & 104 & 110 & 108 & 109 & 105 \\
\hline $\begin{array}{l}\text { Carbon dioxide } \\
(\mathrm{mmol} / \mathrm{L})\end{array}$ & $23.0-31.9$ & 17 & 18 & 18 & 22 & 26 & 24 & 27 \\
\hline $\begin{array}{l}\text { Urea Nitrogen } \\
(\mathrm{mg} / \mathrm{dL})\end{array}$ & $8-25$ & 69 & 72 & 71 & 70 & 65 & 36 & 31 \\
\hline $\begin{array}{l}\text { Creatinine } \\
(\mathrm{mg} / \mathrm{dL})\end{array}$ & $0.6-1.5$ & 5.1 & 4.7 & 4.1 & 3.5 & 2.0 & 0.9 & 0.9 \\
\hline $\begin{array}{l}\text { Glucose } \\
\text { (mg/dL) }\end{array}$ & $70-110$ & 74 & 115 & 96 & 102 & 116 & 102 & $|3|$ \\
\hline $\begin{array}{l}\text { Calcium } \\
\text { (mg/dL) }\end{array}$ & $8.5-10.5$ & 7.4 & 7.6 & 7.9 & 7.5 & 7.9 & 8.6 & 8.9 \\
\hline $\begin{array}{l}\text { Magnessium } \\
(\mathrm{mg} / \mathrm{dL})\end{array}$ & I.4-2.8 & - & - & 2.2 & - & 2.0 & - & - \\
\hline $\begin{array}{l}\text { Osmolality } \\
(\mathrm{mOsm} / \mathrm{kg})\end{array}$ & 278-305 & - & - & - & 303 & - & - & - \\
\hline
\end{tabular}

Notes: ${ }^{a}$ To convert the values for urea nitrogen to millimoles per liter, multiply by 0.357 . To convert the values for creatinine to micromoles per liter, multiply by 88.4 . To convert the values for glucose to millimoles per liter, multiply by $0.555 \mathrm{I}$. To convert the values for calcium to millimoles per liter, multiply by 0.250 . To convert the values for magnesium to millimoles per liter, multiply by 0.25 . Trend of rising sodium after giving sodium polystyrene sulfonate (SPS) treatment for hyperkalemia. Patient received a total of four doses of $60 \mathrm{~g}$ SPS in less than 24 hours, thereby raising the sodium level up to $15 \mathrm{I}$ mmol/L, which was normalized by free water hydration.

developed diarrhea over the next hours. A total of $240 \mathrm{~g}$ of SPS was administered during a 24-hour period, before the discontinuation of this order. Her serum sodium started at $140 \mathrm{Meq} / \mathrm{L}$ and then decreased to $128 \mathrm{mEq} / \mathrm{L}$. Twenty-four hours after admission, her sodium level was $141 \mathrm{mEq} / \mathrm{L}$, then increased over the second hospital day to $151 \mathrm{mEq} / \mathrm{L}$. During the first 2 days in the hospital she passed large amounts of liquid stool. Given the concerning rate of serum sodium rise, an infusion of dextrose water solution was administered and sodium levels were closely monitored. Her thyroid and adrenal function were adequate. Her serum sodium normalized over the next 3 days with replacement of the free water deficit. Her renal function and potassium levels returned to normal. Her low fractional excretion of sodium and physical signs of volume depletion led us to believe that the net free water loss due to SPS-induced diarrhea resulted in this patient's hypernatremia rather than a sodium-potassium exchange mechanism. The patient had no major long-term neurologic complications.

\section{Discussion}

SPS is a cation exchange resin used to induce a net potassium loss in patients with moderate to severe hyperkalemia. With the growing chronic kidney disease and end stage renal disease patient population, hyperkalemia is a relatively common electrolyte abnormality encountered in clinical practice. SPS is commonly used when serum potassium levels are high as an adjunct medical treatment measure. Although its safety and efficacy are being questioned, ${ }^{4}$ the mechanism of action of SPS is thought to be the net exchange of potassium in the intestinal lumen with sodium in order to maintain electrical neutrality. Each gram of resin may bind as much as $1 \mathrm{mEq}$ of potassium and exchange it for $1-2 \mathrm{mEq}$ of sodium. To facilitate the passage of the resin through the gastrointestinal tract, sorbitol was added to the resin, resulting in a cathartic effect. ${ }^{2}$ Complications of SPS therapy, although rare, include ischemic colitis and colonic necrosis, ${ }^{2,4}$ hypocalcemia, ${ }^{5}$ volume overload, and iatrogenic hypokalemia.

The hypernatremia in our patient is likely due to net intestinal water loss, in the setting of profuse osmotic diarrhea induced by SPS therapy. It is unclear whether salt loading from the cation exchange mechanism played a role in the pathogenesis. Only two cases of combined water loss combined with a sodium loading have been reported in the literature, both in low birth neonates. ${ }^{3}$ In our patient, the relatively rapid correction of hyponatremia may also have been contributed to by antidiuretic hormone suppression in the setting of the restoration of intravascular volume. Although the relative change 
of serum sodium was significant, the patient's serum sodium returned to the initial normal value within the first hospital day and then increased by $9 \mathrm{mEq} / \mathrm{L}$ in the next 24 hours. This change was slightly higher than the currently recommended rates of change, ${ }^{6}$ but there were no adverse clinical consequences observed in long-term follow-up.

This case illustrates a potential side effect of excessive administration of SPS in hospitalized adults. As a quality improvement measure, our institutional pharmacy no longer accepts standing orders for SPS. We hope to raise awareness of this potential side effect of SPS among the medical community.

\section{Disclosure}

The authors report no conflicts of interest in this work.

\section{References}

1. Flinn RB, Merrill JP, Welzant WR. Treatment of the oliguric patient with a new sodium-exchange resin and sorbitol. $N$ Engl J Med. 1961;264: 111-115.

2. Rashid A, Hamilton SR. Necrosis of the gastrointestinal tract in uremic patients as a result of sodium polystyrene sulfonate (Kayexalate) in sorbitol: an underrecognized condition. Am J Surg Pathol. 1997;21: 60-69.

3. Sterns RH, Rojas M, Bernstein P, et al. Ion-exchange resins for treatment of hyperkalemia: are they safe and effective? J Am Soc Nephrol. 2010;21(5):733-735.

4. Filippi L, Cecchi A, Dani C, et al. Hypernatraemia induced by sodium polystyrene sulphonate (Kayexalate) in two extremely low birth weight newborns. Paediatr Anaesth. 2004;14(3):271-275.

5. Ng YY, Wu SC, Cheng CT, et al. Reduction of serum calcium by sodium sulfonated polystyrene resin. J Formos Med Assoc. 1990;89: 399-402.

6. Sterns RH, Hix JK, Silver S. Treatment of hyponatremia. Curr Opin Nephrol Hypert. 2010;19(5):493-498.

\section{Publish your work in this journal}

The International Journal of Nephrology and Renovascular Disease is an international, peer-reviewed open-access journal focusing on the pathophysiology of the kidney and vascular supply. Epidemiology, screening, diagnosis, and treatment interventions are covered as well as basic science, biochemical and immunological studies. The journal welcomes original research, clinical studies, reviews \& evaluations, expert opinion and commentary, case reports and extended reports. The manuscript management system is completely online and includes a very quick and fair peerreview system, which is all easy to use. Visit http://www.dovepress.com/ testimonials.php to read real quotes from published authors.

\footnotetext{
Submit your manuscript here: http://www.dovepress.com/international-journal-of-nephrology-and-renovascular-disease-journal
} 